\title{
Formulating a Policy for Developing Regional Solid Waste Final Disposal Installation in East Java Province
}

\author{
Penyusunan Kebijakan Pengembangan Tempat Pemrosesan Akhir \\ Sampah Padat Regional di Provinsi Jawa Timur
}

\author{
Hitapriya Suprayitno $^{1, a)}$ \& Bieby Voijant Tangahu ${ }^{2, b)}$ \\ ${ }^{1)}$ Department of Civil Engineering, Institut Teknologi Sepuluh Nopember (ITS), Surabaya. \\ ${ }^{2)}$ Department of Environmental Engineering, Institut Teknologi Sepuluh Nopember (ITS), Surabaya. \\ E-mail : ${ }^{\text {a) }}$ suprayitno.hita@gmail.com \& b)bieby2003@gmail.com
}

\begin{abstract}
Solid Waste Final Disposal Installation is capital for urban area. Meanwhile, cities, in general, do not have enough space to build Final Disposal Installation. They need to collaborate with the neighboring district. Such collaboration does not always run well. Therefore, provincial government needs to participate in it by developing Regional Final Disposal Installation to be used together. A policy, for developing this, need to be formulated. A special method, Step by Step Highest Solution Reduction by Needs and Constraints, has been used to formulate the policy. The main policy formulation for developing Regional Solid Waste Final Disposal Installation consists of several following lines : to develop Regional Final Disposal Installation for all cities step by step in function of the city needs; to develop incineration type final disposal step by step in function on the financial disponibility; to push the rich cities to develop solid waste incineration step by step; to push implementation of 3R techniques starting from intermediate disposal installation step by step; to forbid the utilization of open truck for transporting domestic solid waste from intermediate disposal to final disposal step by step; to maintain the existing city sanitary landfill final disposal and transforming it into incineration installation step by step; to promote facilitiies installation made by Indonesian industry, to develop a good institutional arrangement for the Regional Final Disposal Installation.
\end{abstract}

Keywords : infrastructure asset management, infrastructure policy, domestic solid waste, solid waste final disposal installation, regional final disposal installation.

\section{INTRODUCTION}

Infrastructure Asset Management (IAM), among others, deals with infrastructure development policy as a pre-life-cycle step. One of vital and capital infrastructure for urban area is Solid Waste Final Disposal Installation (SWFDI) (Damanhuri \& Padmi 2010; Suprayitno \& Soemitro 2018). Therefore, knowing how to Formulate a Policy and the Policy itself for a SWFDI and Regional Solid Waste Final Disposal Installation (RSWFDI) Development is one of important knowledges for IAM.

For the urban area, as a very dense populated area, waste management is very complicated and serious problem. Wastes are generated in enormous amount, with big difficulties to find places to proceed and to dispose the waste. We can find easily all type of wastes : either solid waste, liquid waste or gaseous waste; hazardous or non hazardous waste; 
domestic, industrial, or hospital wastes; organic or inorganic waste; and any other types (Damanhuri 2006; Damanhuri \& Padmi 2010; Hoornweg \& Badha-Tata 2012; Maulana, Kusnanto \& Suwarni 2015).

Cities has a limited administrative area, while its area is very dense. In Indonesia, SWFDIs are still built in sanitary landfill. Therefore, they do not have enough space for developing a SWFDI. Thus, a city must collaborate with its surrounding regency for developing their SWFDI together. Quite often, such collaboration does not run well. Cases for Bus Terminal Type A and Bus Terminal Type B indicate this phenomenon. The Surabaya City Government and the Sidoarjo Regency Government dispute in a long time for the existence of Purabaya Bus Terminal Type A. The bus terminal was built by Surabaya City but located in Sidoarjo Regency Area. Faced with several similar serious problem the Ministry of Transport decide a Policy that the operating all of Type A Bus Terminal must be on national responsibilities and all of Type B Bus Terminal must be on provincial responsibilities (Aliyah 2012; Amiruddin 2015; DetikNews 2014). Referring to the above problem, the Provincial Government need to solve the problem by developing a Regional SWFDI for the city and the surrounding sub-urban area.

On the other hand, in developed countries, like Singapore the neighboring country for example, sanitary landfill has been abandoned since several years ago. Singapore use mainly huge Waste to Energy (WTE) incinerators. Others developed country, like Japan, France, Austria, USA, China are the same (Gentil 2013; Lee 2010; MoE 2012; Thon 2013).

Domestic Solid Waste Management is very regulated in Indonesia. There are a number of related Codes and Regulations. Among three related codes, one code regulate directly the Waste Management (UU 18/08), another is about local government in which waste management is directly under the responsibility of city and district local government (UU23/14) and one code directly regulate the environmental protection and management, inwhich the waste is also regulated (UU 32/09). Four Government Regulations regulate the domestic waste, hazardous waste, permission related to environment, and share of responsibilities among central, provincial, city and district government (PP18/12, PP 101/14, PP 27/12, PP 38/07). Three Ministry Regulations regulate the facilities for waste management, the people based sanitation system and waste management guideline (Permen PU 3/13, Permen Kes 3/14, Permen Dagri 33/10). East Java Provincial Regulation regulate the regional waste management (Perda Jatim 4/10). Two Surabaya City Regulations regulate about waste management in the city and about waste management retribution for Surabaya City (Perda Kota Surabaya 5/04, Perda Kota Surabaya 4/00).

This paper present a reflection for Policy Formulation to develop Regional SWFDI for cities in East Java Province.

\section{RESEARCH METHOD}

The research was carried out by following these steps : formulating research objective, executing literature review, designing policy formulation method, identifying existing condition, formulating ideal solution, identifying the needs and constraints, formulating the policy.

\section{LITERATURE REVIEW}

\section{Infrastructure Policy}

Infrastructure Policy can be defined as a set of guidelines for developing or managing a certain infrastructure. All of strategic plan and annual plan must be oriented toward the policy. The Policy normally is designated for a certain rather long period of time, say 5-20 years. The guideline may concern principal technical requirement, financial arrangement, 
institutional arrangement and other aspects (Brooks 2010; Mor 2017). One of the Infrastructure Policy instruments is the Regional Spatial Master Plan, as a Regional Regulation (Peraturan Derah), decreed by Regional Legislative Institution.

\section{Solid Waste Management System in Indonesia}

Solid waste, in general, can be classified as hazardous or non hazardous solid waste; and also as domestic waste, industrial waste, or medical waste. The hospital, as the generator of hazardous medical solid waste, must have special incinerator for incinerating those hazardous waste. Big industries or industrial estate usually must be equipped with needed incinerator also. It can be sludge incinerator and the other special incinerator, if it is needed (Damanhri 2006; Damanhuri \& Padmi 2010; Permen LH 5/12).

Managing domestic solid waste management, even as non hazardous solid waste, is not simple at all, caused by its volume which is enormous and by its generator which is spreaded all over the city. In Indonesia, the basic treatment for domestic solid waste is by collecting the garbage into intermediate disposal posts from the waste generator, and then collected them from the intermediate disposal posts, to dispose them in the final disposal installation. In Indonesia nowadays, final disposal installation, practically, all of them are sanitary landfill. Utilization of incinerator just to be started in very small scale. Utilisation of Compcted Garbage Truck combined by using garbage bin, thus without intermediate disposal post, can be found in Jakarta and Surabaya on very limited number. In Indonesia solid waste generation is around 1.5 litres/person/day or 0.25 ton/person/day (Damanhuri \& Padmi 2010; Sal 2018; Ruslinda, Indah \& Laylani 2012).

\section{Solid Waste Final Disposal Installation in Big Cities in Indonesia}

Solid Waste Final Disposal Installation in big cities in Indonesia, e.g. Jakarta, Surabaya, Bandung, Yogyakarta and Malang are all still with sanitary land-fill. The waste transportation still use a lot of open truck. The 3R (reduce, reuse, recycle) management do not run well yet. The systems still have a lot of environmental problem : lychee, stinky, crowded, and health problem. Jakarta, Bandung, Yogyakarta, Mojokerto must use Final Disposal outside the city, for which a collaboration with neighboring district is necessary. Example of several sanitary landfill are presented in Table 1 as follows.

Table 1. Final Disposal in Several Big Cities in Indonesia

\begin{tabular}{llll}
\hline City & Final Dis posal & Location & Type \\
\hline \multirow{2}{*}{ Jakarta } & TPA Rawa Kucing & Tangerang City & Sanitary Landfill \\
& TPA Bantar Gebang & Bekasi City & Sanitary Landfill \\
Surabaya & TPA Benowo & Surabaya & Sanitary Landfill \\
Bandung & TPA Sarimukti & Cipatat, West Java Regency & Sanitary Landfill \\
Yogyakarta & TPA Piyungan & Piyungan, Bantul Regency & Sanitary Landfill \\
Malang & TPA Supit Urang & Malang City & Sanitary Landfill \\
Mojokerto & TPA Mojosari & Mojosari, Mojokerto Regency & Sanitary Landfill \\
\hline
\end{tabular}

\section{Solid Waste Management in Developed Countries}

Solid Waste Management in Singapore is already very modern, efficient and healthy. The solid waste collection system is very modern, Singapore does not use intermediate disposal posts, the garbage are collected directly by compacted garbage trucks from garbage container at the local disposal point distributed all over the city. The garbage are collected and proceed in four WTE incinerator : Tuas, Senoko, Tuas South, Keppel. The WTE incinerator can reduce the waste volume by $90 \%$. Still, there are $10 \%$ of bottom ash resulted from the 
incineration that must be dumped. Singapore use Semakau island for final disposal of bottom ash in sanitary landfill. Apart from it, Singapore implement the 3R program quite seriously and successful. For its fifth and sixth WTE, Singapore will use PPP scheme. List of the WTE Incinerator is presented in Table 2 below (Lee 2010).

Table 2. Singapore WTE Incinerators

\begin{tabular}{ccccc}
\hline \multirow{2}{*}{ No } & \multirow{2}{*}{ WTE } & \multirow{2}{*}{ Year } & Capacity & Capital Cost \\
\cline { 4 - 5 } & & & ton/day & $\$$ million \\
\hline 1 & Tuas & 1986 & 1700 & 200 \\
2 & Senoko & 1992 & 2100 & 560 \\
3 & Tuas South & 2000 & 3000 & 890 \\
4 & Keppel Sheggers & 2009 & 800 & 160 \\
\hline
\end{tabular}

All developed countries are already used the same system as the system used in Singapore. WTE Company are already exist in several developed countries, among others are : Mitsubishi Huizen - Japan, C\&G - Hong Kong, Keppel Seghers - Singapore. They operate either as installation development contractor, installation operator, or installation investor (C\&G 2012; JETRO 2018; Tuan 2016).

\section{Waste Incinerator Installation in Indonesia}

Solid Waste Incinerator has been installed and used quite a lot in Indonesia. The incinerators are mostly used in the hospital, industry and crematorium facilities. Incinerator for Domestic Solid Waste has been also installed in several palaces in small capacities. Big capacity incinerators for Domestic Solid Waste cannot be found in Indonesia. It has been operated once in Surabaya, but now it has been closed and demolished. In several places, the incinerators are started to be used for incinerate domestic solid waste, like in Karawang Regency, in Nurul Harmainlah Islamic Boarding School (Pesantren Nurul Harmainlah) in Lombok, in TPS Benda Baru in South Tangerang City, in TPA Karya Jaya in Palembang City, and in PPS Saboga ITB in Bandung City. Examples of Incinerator Installation in Indonesia are presented in Table 3, Table 4 and Table 5 below (Fery 2018; Huda 2013; JAS 2004; Maulana et al 2015; Redaksi 2016; Redaksi Lombok Post 2016).

Table 3. Example of Incinerator Installation in Hospital

\begin{tabular}{clll}
\hline No & Hos pital & Location & Incinerator \\
\hline 1 & RSAL dr. Ramelan & Surabaya & $1 \mathrm{~m}^{3} / \mathrm{hr}$ \\
2 & RSUD Payakumbuh & Payakumbuh & $50-75 \mathrm{~kg} / \mathrm{hr}$ \\
3 & RSUD M. Yunus & Bengkulu & $10-20 \mathrm{~kg} / \mathrm{hr}$ \\
4 & RS Jiwa & Bengkulu & $10-20 \mathrm{~kg} / \mathrm{hr}$ \\
\hline
\end{tabular}

Table 4. Example of Incinerator Installation in Industry

\begin{tabular}{lllll}
\hline \multirow{2}{*}{ No } & Industry & Location & Incine rator & \multicolumn{2}{c}{ Capacity } \\
\hline \multirow{2}{*}{1} & PT Aneka Tambang & Pomala, Sulawesi & Hazardous Sludge Oil & $200-2501 / \mathrm{hr}$ \\
& & Hazardous Solid Waste & $135 \mathrm{~kg} / \mathrm{hr}$ \\
2 & PT Rekayasa Hijau Indonesia & Bandung, West Jawa & Medical Waste & $50-75 \mathrm{~kg} / \mathrm{hr}$ \\
3 & PT Desa Air Cargo & Batam & Hazardous Solid Waste & $350-400 \mathrm{~kg} / \mathrm{hr}$ \\
4 & PT Kramayudha Ratu Motor & Jakarta & Hazardous Solid Waste & $125 \mathrm{~kg} / \mathrm{hr}$ \\
\hline
\end{tabular}


Table 5. Example of Small Capacity Domestic Solid Waste Incinerator Installation

\begin{tabular}{|c|c|c|c|c|}
\hline \multirow{2}{*}{ No } & \multirow{2}{*}{ Institution } & \multirow{2}{*}{ Location } & \multicolumn{2}{|l|}{ Incine rator } \\
\hline & & & Model & Capacity \\
\hline 1 & Pesantren Nurul Haramain lah & Narmada, Lombok & Incinerator made by Pesantren & 12 ton/day \\
\hline 2 & PPS - Saboga, ITB & Bandung & Incinerator made by PPS & no info. \\
\hline 3 & TPA Karya Jaya - City & Palembang & being planned & no info. \\
\hline 4 & TPS Benda Baru & South Tangerang & PT PITS & $75 \mathrm{~m} 3 /$ day \\
\hline 5 & PemKab Karawang & Karawang & no info. & no info. \\
\hline
\end{tabular}

\section{Incinerator Supply in Indonesian Market}

Incinerator supply in Indonesian market is quite advanced for small to medium capacity. Indonesia has at least six incinerator producer, mentioned as follows : PT. Karya Mitra Usaha in Bogor, Metalindo Erabuana Engineering in East Jakarta, AJM Medical in Surabaya, Centra Rekayasa Enviro in Bandung, Maxpell Technology in Cimahi and PT Pembangunan Investasi in South Tangerang City. They grouped in an association : Asosiasi Produsen Insinerator Indonesia (APII). They produce incinerator and related equipment in wide range of capacity for several types. Those six companies have implemented a lot of incinerators throughout Indonesia (AJM 2017; MEE 2018; KMU 2018). Several incinerator types and capacity ranges are presented in the following Table 6.

Table 6. Several Incinerator Type and Capacity, produced by Indonesian Company

\begin{tabular}{cll}
\hline No & Type & Capacity Range \\
\hline 1 & Medical Waste Incinerator & $10 \mathrm{~kg}-300 \mathrm{~kg} / \mathrm{batch}$ \\
2 & Hazardous Waste Incinerator & $20 \mathrm{~kg}-300 \mathrm{~kg} / \mathrm{batch}$ \\
3 & Domestic Solid Waste Incinerator & $10 \mathrm{~kg}-75 \mathrm{~kg} / \mathrm{batch}$ \\
4 & Sludge Incinerator & no information \\
5 & Integrated Incinerator & $100 \mathrm{~kg}-300 \mathrm{~kg} / \mathrm{batch}$ \\
6 & Portable Mobile Incinerator & $5 \mathrm{~kg}, 10 \mathrm{~kg}, 15 \mathrm{~kg} / \mathrm{batch}$ \\
\hline
\end{tabular}

\section{POLICY FORMULATION}

\section{Policy}

A Policy is a guide-line or a directive toward which all of action plans, either strategic plan or annual plan, must be oriented, for a certain period of time. As a Public Policy, it must be in concordance with related existing codes and regulations.

This paper is limited merely on the Policy Design for the Technical Aspects of the Domestic Solid Waste Management. The financial and institutional aspects are not included in this paper.

\section{Problem Statement}

All of 9 cities, in East Java, still use sanitary landfill for their final disposal installation. Meanwhile, cities have limited area to develop their sanitary landfill. City are already or soon have to use final disposal outside the city, means on the neighboring kabupaten. Cooperation are needed by the cities. Cooperation are not always run smoothly. Therefore Regional Final Solid Waste Disposal Installation (RFSWD) organized by Provincial Government are needed.

The main questions then are, which city need RFSWD? When will they need it? what kind of RFSWD they need? where will the RFSWD be built? Which technology that should be used? What kind of collection system that will be applied? How is the institutional 
arrangement? How is the financial arrangement? A Policy for Developing RSWFDI to address all of those questions is necessary.

\section{Objective}

The objective of the policy is for giving a direction in developing a good solid waste management in urban area. The development must refer to developed countries system. Singapore should be used as a reference toward which the policy must be oriented. Besides, it should be oriented to use the domestic industrial product for developing the SWFDI.

\section{Horizon Year and Staging Year}

For this kind Policy Formulation, a horizon year is needed. The horizon year is set for the year 2031. Staging year for step by step achievement is not needed for this purpose. The staging year is needed for developing Development Strategy, which is, in this case, a derivation of the Policy.

\section{East Java City's SWFDI Data}

Among the nine East Java cities, all use sanitary landfill as their final disposal type. The Mojokerto city already use the final disposal outside the city. Data on East Java City density and its SWFDIs are presented in Table 7 below.

Table 7. East Java Cities Data Related to SWFDI

\begin{tabular}{llrrccc}
\hline No City & $\begin{array}{r}\text { Area } \\
k m 2\end{array}$ & $\begin{array}{r}\text { Pop } \\
\text { person }\end{array}$ & $\begin{array}{r}\text { Density SWFDI } \\
\text { person/km2 }\end{array}$ & Location & Type \\
\hline 1 & Surabaya & 350.54 & $2,765,908$ & 8,304 TPA Benowo & & \\
2 & Malang & 145.28 & 857,891 & 7,800 TPA Supit Urang & & \\
3 & Madiun & 33.92 & 386,437 & 5,981 TPA Winongo & sanitary \\
4 & Kediri & 63.4 & 287,435 & 4,318 TPA Ngadirejo & city & landfill \\
5 & Probolinggo & 56.67 & 200,000 & 7,924 TPA Sukabumi & & \\
6 & Batu & 136.74 & 182,392 & 900 TPA Tlekung & & \\
7 & Blitar & 32.57 & 131,968 & 3,891 TPA Ngegong & & \\
8 & Mojokerto & 16.47 & 130,196 & 6,792 TPA Mojosari & kabupaten & \\
9 & Pasuruan & 35.29 & 103,000 & 5,991 TPA Blandongan & city & \\
\hline
\end{tabular}

\section{Policy Formulation Method}

A method for formulating a policy has been thought specially for this purpose. The Method is called Step by Step Highest Solution Reduction by Needs and Constraint (SSHSRNC). It is about setting an idealistic solution formulation, which might be very difficult or even impossible to achieve. The Highest Solution then step by step is reduced by the needs and by the constraints, in order to obtain a Rational Policy to be set up and implemented.

\section{The Ideal Solution Could Be, the Related Existing Solution Components, the Related Needs, and the Related Constraints}

The Policy Formulation Method need the Highest/Ideal Solution, the Related Needs, the Related Constraints and the Related Existing Conditions. These four data are presented one by one as follows.

The Ideal Solution Could Be

Solid Waste Management System in Singapore is set to be the Ideal/Highest Solution System. Singapore is equipped the whole city with 4 incinerators for their final disposal installation, all of them are already Waste to Energy (WTE) huge incinerator type. Singapore 
does not use any Intermediate Waste Disposal, the garbage are dispose in containers for various sizes, then the Compacted Garbage Trucks moving around the city to dump the garbage into the truck from the containers. All garbages are incinerated in the WTEs. The WTEs still produce $10 \%$ volume of bottom ash which is dump in a sanitary landfill special for this ash at Semakau small island. The Reduction, Recycling and Reused management is well implemented in Singapore. The whole management system is operated together by state owned enterprise and private enterprise.

\section{The Existing Related Solution Components}

Meanwhile, several facts related to the ideal solutions must be noted. These facts need to be considered. The existing conditions needs to be considered are incinerator has been used extensively in Indonesia for hospital and industry, Indonesia is already capable of producing small - medium capacity incinerator, incinerator installation for domestic solid waste has been installed and are being to be installed in several places, garbage container and compacted garbage truck are started to used in Indonesia, practically each city use sanitary landfill, the 3R system is not yet well implemented, each city still use intermediate disposal system, each city has experience to operate the UPT and BUMD system.

\section{The Related Needs}

The timings of the Needs for SWFDI are varied from one city to the others. Mojokerto City, for example, nowadays already use the SWFDI situated in Mojokerto District Surabaya City may still able to use its sanitary landfill for several years ahead. So, the Needs for each city needs SWFDI outside the city for different year.

\section{The Related Constraints}

Each city has the same type of Constraints in different magnitude or scale. The classical constraints are the fund needed for developing SWFDI, the management system capability, and the human resources capacity.

As promoting the Indonesian product to be used in SWFDI, the domestic industrial capabilities to produce the incinerators or the WTE must be considered as constraints. But this constraints need to be loosen step by step.

\section{Developing Policy Design}

By using the method Step by Step Highest Solution Reduction by Needs and Constraints (SSHSRNC), the development of Policy Design was executed in several step. Step 0 consists of formulating Related Existing Condition, Highest Solution, Needs and Constraints. The next steps is executing Step by Step Reduction. The Policy development process, step by step, is presented below.

\section{- Step 0 : Setting the Existing Facts and Highest Solution}

- Related Exsisting Condition :

- All of the 9 cities still use sanitary landfill, all of the 9 cities still use Intermediate Disposal Point system, open garbage truck are still used a lot, container hauled truck are also started to be used, 3R system just recently implemented with still minimum coverage, cultivating methane gas from sanitary landfill has been tried

- Incinerator are widely used already in hospital and industry; small-medium capacity incinerator can be produced by Indonesian industry already; and several communities are already implement small scale incinerator., outside East Java

- Example of few successful cooperatiosn between a city and a kabupten for developing SWFDI are exist, certain are with lot of difficulties. 
- Needs : the year the 9 cities need to have sanitary landfill outside the city are not the same.

- Constraints : procuring sanitary landfill is much cheaper than incinerator, practically the cities does not enough fund to procure at an instance the WTE incinerator.

- Highest Solution : equipped all cities instantly with solid waste WTE incineration installation as much as needed, no sanitary land fill at all, no intermediate disposal points, garbage collection by using special garbage bin and compacted garbage truck system, $3 \mathrm{R}$ implementation in all coin as needed, and use domestic produced incinerator.

\section{- Step 1 : Step 0 - The Needs}

- Needs : the year the 9 cities needs to have sanitary landfill outside the city are not the same.

- Step 1 Solution : equippedall cities and districts by WTE incinerator system step by step depends on each needs and funding capacity.

\section{- Step 2 : Step 1 - Constraints}

- Constraint : not all cities ready to have incinerator, not all cities have enough money, WTE very expensive, domestic industry capability up to medium size incinerator.

- Supporting Facts : incinerator for domestic solid waste has been installed in several places outside East Java

- Develop the domestic incinerator industry capability to produce bigger capacity incinerator.

- Step 2 Solution : install medium sizes incinerator in all city and kabupten, in order to make city and district get used to; install in each sanitary landfill as preparation for full-scale incineration; incite the big community to install incinerator : big real estate, campuses, military complexes, industrial estate; keep sanitary landfill area for future WTE incinerator location; participate in building Regional Incinerator for provincial government; and to develop domestic incinerator industry capability.

\section{- Step 3 : Final Formulation}

- Toward Modern Domestic Solid Waste Management for all Cities and Districts : WTE incinerator, healthy garbage transportation by using garbage bin (garbage container) and compacted garbage trucks, no intermediate disposal but garbage bin pooling, well 3R implementation. The whole are implemented step by step for all cities and districts.

- Step of implementation : encourage each cities and districts to install domestic solid waste incinerator, even if only medium capacity, encourage not to use open truck to transport the garbage, do not eliminate the local of sanitary landfill but use it for future WTE incinerator, use domestic product incinerator, encourage domestic incinerator industry to produce high capacity WTE incinerator, promote 3R.

- Institutional and Financial Aspects must be studied.

\section{Policy Formulation}

The Policy is formulated is follows. Toward modern Solid Waste Management System with no sanitary landfill, use WTE installation, no intermediate disposal points, waste transportation system by using container (garbage bin) with crushed garbage truck, sanitary landfill for WTE bottom ashes, a good overall 3R system implementation. These all should be achieved step by step, depends on the industry capability and financial capacity. Make the whole system get used to the modern system step-by-step, lead by small scale installation of 
domestic waste incinerator for each city and district and by using domestic incinerator product.

\section{CONCLUSIONS}

For this research concerning policy formulation for developing Regional Final Disposal Installation, several interesting and important conclusions can be drawn and presented as follow.

- Policy is a guideline or a directive toward which all of action plans, either strategic plan or annual plan, must be oriented, for a certain period of time. As Public Policy, it must be in conformity with related existing codes and regulations.

- A special method was created and used to formulate this policy : Step by Step Highest Solution Reduction by Needs and Constraint (SSHSRNC).

- Modern Domestic Solid Waste Management has abandoned sanitary landfill type. It implement extensively and deeply the 3 R system, use the WTE incinerator system with no intermediate disposal and with waste transportation by using garbage bin and compacted garbage truck, and use sanitary landfill for WTE bottom ashes.

- WTE Company are exist already in several developed countries.

- The existing Municipal Waste Management in Indonesia still use sanitary landfill type, with intermediate disposal points and still use quite a big proportion of open truck garbage to transport from the intermediate to the final disposal point. In general, the sanitary landfill are already in critical condition, either in terms of capacity, operation, and health condition.

- Waste incinerator are already widely used especially in hospital and industry. Indonesian industry already has the capacity to produce various type of small to medium capacity incinerator. Several communities already use incinerator for their domestic solid waste.

- The Policy is based on the theme "Toward modern Solid Waste Management System with no sanitary landfill, use WTE installation, no intermediate disposal points, implement waste transportation system by using container (garbage bin) with compacted garbage truck, use sanitary landfill for WTE bottom ashes, implement a good overall 3R system implementation, and promoting the use of domestic industry products".

- to develop Regional Final Disposal Installation for all cities, step by step, in function of the city needs, based on incineration system.

- to develop incineration type final disposal for each city and district, step by step, in function on the financial disponibility.

- to push the rich cities to develop solid waste incineration step by step.

- to push implementation of 3R techniques starting from intermediate disposal installation step by step.

- to forbid the utilization of open truck for transporting domestic solid waste from intermediate disposal to final disposal, use rather container haul system, step by step.

- to maintain the existing city sanitary landfill final disposal and transforming it into incineration installation, step by step.

- to promote the domestic industry to produce high capcity incinerator and WTE incinerator.

- to develop a good institutional arrangement for the Regional Final Disposal Installation

This research should be continued, extended and developed by doing research on : deepening the understanding of the public policy, formulating policy for other types of infrastructure, developing the method to formulate infrastructure policy, developing 
infrastructure development strategy and especially East Java RFDI development strategy, developing infrastructure characteristics knowledges needed in formulating infrastructure policy and development strategy.

The method for Policy Formulation is a new method and it seems powerful. So, it is necessary to be named for the easiness of denoting it. The method is called as Step by Step Highest Solution Reduction by Needs and Constraint (SSHSRNC). In Indonesian language, it is called as Reduksi Bertahap Solusi Tertinggi Berbasis Kebutuhan dan Kendala (RSTBBKK).

Notes. This paper has been written as part of academic inputs preparation for the East Java Province Spatial Master Plan Review in year 2018.

\section{REFERENCES}

AJM (2010). "Produk Incinerator”. Brosur Produk. AJM Medical. Surabaya.

Aliyah, H. (2012). "Konflik dalam Pelaksanaan Kerjasama antara Pemerintah Kota Surabaya dengan Pemerintah Kabupaten Sidoarjo dalam Pengelolaan Terminal Purabaya". Skripsi Tesis. Fakultas Sospol. Universitas Airlangga. Surabaya.

Amiruddin, M.T. (2010). "Konflik Kewenangan Pemerintah Kota Surabaya dan Pemerintah Kabupaten Sidoarjo dalam Pengelolaan Terminal Purabaya”. Skripsi. Fakultas Sosial Politik. Institut Agama Islam Negeri Sunan Ampel. Surabaya.

Brooks, Jonathan (2010). "Principles for Effective Policy Design". OECD Working Paper.

C\&G (2012). A Leading Waste to Energy Investor and Operator - Corporate Presentation 2012. C\&G Environmental Protection Holdings Limited. Hong Kong.

Damanhuri, Enri (2006). "Teknologi dan Pengelolaan Sampah Kota di Indonesia”. Workshop Nasional Biokonversi Limbah, 11-12 Aprl 2006, Malang. Universitas Brawijaya.

Damanhuri, Enri \& Padmi, Tri (2010). "Pengelolaan Sampah". Diktat Kuliah TL-3104 Versi Tahun 2010. Program Studi Teknik Lingkungan. FSTL. Institut Teknologi Bandung.

DetikNews (2014). "Polemik Terminal Purabaya, Pemkot Surabaya minta PemKab Sidoarjo Tahu Diri”. DetikNews, Jum'at, 14 November 2014.

Fery (2018). "Insinerator TPA Karya Jasa Segera Dibangun”. Ampera.com, 25 April 2018, Kolom : Home > Palembang.

Gentil, E.C. (2013). Municipal Waste Management in France. European Environment Agency. Paris.

Hoornweg, Daniel \& Badha-Tata, Perinaz (2012). "What a Waste, A Global Review of Solid Waste Management". Urban Development Series, Knowledge Papers. The World Bank.

Huda, Nida Nurul (2013). "Prof. Dr. Ir. Eri Damnhuri : Pelopor Insinerator Perguruan Tinggi di Indonesia". www.itb.ac.id. Selasa, 1 Oktober 2013, Kolom : News > Profil.

IE Singapore (2012). "Waste Management - World Class Environmental and Waste Management Services". International Enterprise Singapore. Singapore.

JAS (2004). "Pemkab Karawang Sebar Insinerator di Sejumlah Kecamatan". Berita Satu, Jum'at, 29 Agustus, 2004.

JETRO (2018). Japanese Companies Profile - January 9th, 2018. Japan External Trade Organization. Tokyo.

KMU (2018). "Produk Insinerator". Brosur Produk. PD Karya Mitra Usaha. Bogor.

Lee, Christopher (2010). "Solid Waste Management in Singapore". $2^{\text {nd }}$ Regional $3 R$ Forum in Asia, 4-6 October 2010, Kuala Lumpur.

Maulana, M., Kusnanto, H. \& Suwarni, A. (2015). "Manajemen Pengolahan Limbah Padat Rumah Sakit Yogya". Kesmas, Vol. 9, No. 1, Maret 2015, pp. 69-76.

MEE (2010). "Incinerator IS Series - Thermo Q". Brosur Produk. Metalindo Erabuana Engineering. Jakarta Timur 
MoE (2012). "Solid Waste Management and Recycling Technology of Japan - Toward Sustainabile Society". Minsitry of the Environment. Tkyo.

Mor, Federico (2017). "Infrastructure Policy and Investment". Briefing Paper Number 6594, 2 March 2017. House of Common Library.

Redaksi (2016). "Sistem pengelolaan sampah di Benda Baru bisa jadi solusi di Tangsel". Palapa News, Minggu, 24 April 2016.

Perda Jatim 4/10. Peraturan Daerah Provinsi Jawa Timur Nomor 4 Tahun 2010 tentang Pengelolaan Sampah Regional Jawa Timur.

Perda Kota Surabaya 5/04. Peraturan Daerah Kota Surabaya Nomor 5 Tahun 2014 tentang Pengelolaan Sampah dan Kebersihan di Kota Surabaya.

Perda Kota Surabaya 4/00. Peraturan daerah Kota Surabaya Nomor 4 Tahun 2000 tentang Retribusi Pelayanan Persampahan/Kebersihan.

Permen Dagri 33/10. Peraturan Menteri Dalam Negeri Nomor 33 Tahun 2010 tentang Pedoman Pengelolaan Sampah.

Permen Kes 3/14. Peraturan Menteri Kesehatan Nomor 3 Tahun 2014 tentang Sanitasi Total Berbasis Masyarakat.

Permen LH 5/12. Peraturan Menteri Lingkungan Hidup tentang Jenis Rencana Usaha dan/atau Kegiatan yang Wajib Memiliki Analisis Mengenai Dampak Lingkungan Hidup.

Permen PU 3/13. Peraturan Menteri Pekerjaan Umum Nomor 03/PRT/M/2013 tentang Penyelenggaraan Prasarana dan Sarana Persampahan dalam Penanganan Sampah Rumah Tangga dan Sampah Sejenis Sampah Rumah Tangga.

PP 38/07. Peraturan Pemerintah Nomor 38 Tahun 2007 tentang Pembagian Urusan Pemerintahan Pemerintah, Pemerintah Daerah Provinsi, dan Pemerintah Daerah Kabupaten/Kota.

PP 27/12. Peraturan Pemerintah Nomor 27 Tahun 2012 tentang Izin Lingkungan.

PP 81/12. Peraturan Pemerintah Nomor 18 Tahun 2012 tentang Pengelolan Sampah Rumah Tangga dan Sampah Sejenis Sampah Rumah Tangga.

PP 101/14. Peraturan Pemerintah Nomor 101 Tahun 2014 tentang Pengaturan Limbah Bahan Berbahaya dan Beracun.

Redaksi Lombok Post (2016). "Bikin Insenerator Sendiri, Atasi Empat Ton Sampah Sehari". Lombok Post.net, 15 Oktober 2016, Kolom : NTB Terkini > Feature.

Ruslinda, Y., Indah, S. \& Laylani, W. (2012). "Studi Timbulan, Komposisi dan Karakteristik Sampah Domestik Kota Bukittinggi”. Jurnal Teknik Lingkungan UNAND, 9 (1) : 1-12, (Januari 2012).

Sal (2018). "Raperda, Sampah Berceceran saat Diangkut Bisa Dilaporkan". Jawa Pos, Senin, 25 Juni 2018, hal. 18.

Suprayitno, H. \& Soemitro, R.A.A. (2018). "Preliminary Reflection on Basic Principle of Infrastructure Asset Management". Jurnal Manajemen Aset Infrastruktur \& Fasilitas, Vol.2, No. 1, Maret 2018.

Thon, J. (2013). Waste Management in Vienna. Municipal Department 48, City of Vienna. Vienna.

Tuan, Loh Ah. (2016). "Waste-To-Energy Plants - Public Private Partnership Singapore". Keppel Seghers Engineering Singapore Pte Ltd.

UU 32/09. Undang Undang Nomor 32 Tahun 2009 tentang Perlindungan dan Pengelolaan Lingkungan Hidup.

UU 23/14. Undang Undang Nomor 23 Tahun Daerah.2014 tentang Pemerintahan.

UU 18/08. Undang Undang Nomor 18 Tahun 2008 tentang Pengelolaan Sampah. 